\title{
ARISTOTELIAN PHRONESIS AS A KEY FACTOR FOR LEADERSHIP IN THE KNOWLEDGE-CREATING COMPANY ACCORDING TO IKUJIRO NONAKA*
}

\author{
Germán Scalzo *** \\ Guillermo Fariñas****
}

doi: 10.11144/Javeriana.ca031-57.apkfl. Reflection paper. Received: 28/04/2018 and accepted: 14/11/2018. Cite as: Scalzo, G., \& Fariñas, G. (2018). Aristotelian phronesis as a key factor for leadership in the knowledge-creating company according to Ikujiro Nonaka. Cuadernos de Administración, 31(57), 19-44. http://dx.doi.org/10.11144/Javeriana.ca031-57.apkfl.

** Universidad Panamericana, Mexico. E-mail: gscalzo@up.edu.mx

***Universidad Monteávila, Venezuela.E-mail: gfarinasc@uma.edu.ve 
Aristotelian phronesis as a key factor for leadership in the knowledge-creating company according to Ikujiro Nonaka

\section{La frónesis aristotélica como factor clave para el liderazgo en la empresa creadora de conocimiento según Ikujiro Nonaka}

\author{
A frônese aristotélica \\ como fator-chave \\ para a liderança na \\ empresa criadora de \\ conhecimento segundo \\ Ikujiro Nonaka
}

ABSTRACT. In the last decades, there has been an increasing interest on knowledge in the business realm. Japanese scholar Ikujiro Nonaka was among the main theoretical and practical contributors to knowledge creation in organizations, as well as a promoter of including practical reason in the research of business topics such as decision-making, knowledge management, ethics and leadership. In his theory, a Western classical tradition, namely the virtue of phronesis, is combined with the Japanese notion of $B a$ (context-based learning), to explain the way people engage in communities of practice as opportunities for learning. This paper describes his theory of knowledge creation, pointing to phronetic leadership skills as essential drivers of knowledge creation in organizations, in light of the Western classical tradition. Finally, it discusses the scope and limits of Nonaka's contribution, as well as some challenges it posits in order to make the business realm a true space for learning and human flourishing.

Keywords: Nonaka, tacit-explicit knowledge, phronesis, leadership, Ba (context-based learning). JEL Codes: M19

RESUMEN. En las últimas décadas ha habido un creciente interés en el conocimiento en el ámbito empresarial. El académico japonés Ikujiro Nonaka fue uno de los principales contribuyentes teóricos y prácticos para la creación de conocimiento en las organizaciones, así como un promotor de la inclusión de la razón práctica en la investigación de temas de negocios como la toma de decisiones, la gestión del conocimiento, la ética y el liderazgo. En su teoría se combina la virtud de la frónesis, tradición clásica occidental, con la noción japonesa de $B a$ (aprendizaje basado en el contexto), para explicar la forma en que las personas se involucran en las comunidades de práctica como oportunidades de aprendizaje. Este artículo describe su teoría de la creación de conocimiento, señalando las habilidades de liderazgo fronético como motores esenciales de la creación de conocimiento en las organizaciones, a la luz de la tradición clásica occidental. Finalmente, analiza el alcance y los límites de la contribución de Nonaka, así como algunos de los desafíos que plantea para que el ámbito empresarial sea un verdadero espacio para el aprendizaje y el florecimiento humano.

Palabras clave: Nonaka, conocimiento tácito-explícito, frónesis, liderazgo, $\mathrm{Ba}$ (aprendizaje basado en el contexto). Códigos JEL: M19

RESUMO. Nas últimas décadas tem-se incrementado o interesse no conhecimento no âmbito empresarial. O acadêmico japonês Ikujiro Nonaka foi um dos principais contribuintes teóricos e práticos para a criação de conhecimento nas organizações. Igualmente, ele foi um promotor da inclusão da razão prática na pesquisa de temas de negócios como a tomada de decisões, a gestão do conhecimento, a ética e a liderança. Em sua teoria combinam-se a virtude da frônese da tradição clássica ocidental com a noção japonesa de $\mathrm{Ba}$ (aprendizagem baseado no contexto), para explicar a forma em que as pessoas se envolvem nas comunidades de prática enquanto oportunidades de aprendizagem. Este artigo descreve a sua teoria da criação de conhecimento, mostrando as habilidades de liderança fronética como motores essenciais da criação de conhecimento nas organizações, à luz da tradição clássica ocidental. Finalmente, analisa-se o alcance e os limites da contribuição de Nonaka, e alguns dos desafios que ele aponta para que o âmbito empresarial seja um verdadeiro espaço de aprendizagem e florescimento humano.

Palavras chave: Nonaka, conhecimento tácito-explícito, frônese, liderança, $\mathrm{Ba}$ (aprendizagem baseada em contexto). Códigos JEL: M19 


\section{Introduction}

What is knowledge? How is new knowledge created? How is it transmitted? These questions have been studied for many centuries, from disciplines such as gnoseology, epistemology or logic. A few decades ago it started capturing the interest of economic and business sciences. The Japanese thinker Ikujiro Nonaka is among the scholars that have most studied the use, typology, and creation of knowledge applied to the business realm. His approach not only transcends the business world -including contributions from Aristotle, Polanyi, Nishida, Dewey and Whitehead, among others - but also relies on sources beyond the Western tradition, e.g., the Japanese notion of $b a$ is a key idea for understanding his proposals and models. $B a$ is a shared context in motion in which knowledge is created, a concept related to physical or virtual spaces for interaction and learning (Nonaka et al., 2000). Ba refers to "the process of opening up a concrete space or 'lived place' where human beings can encounter each other" (Güldenberg \& Helting, 2007, p. 112).

Nonaka's model rests on the idea of phronesis, the ability to decide successfully and act effectively to achieve an intended purpose. Phronesis is a special type of tacit knowledge that enables one to make prudent decisions and take action appropriate to each situation (Nonaka et al., 2008); it is thus the distinctive feature of leaders. As a subjective and contextual knowledge, it cannot be formalized, but rather is subject to the concrete context and circumstances of time and place in which decisions and actions are made.

The present article addresses the centrality of the notion of phronesis in Nonaka's model, and its importance for understanding organizational action as a learning space. First, we will outline Nonaka's theory of knowledge creation, which is widely documented in his texts over more than twenty-five years. Secondly, phronesis will be pinpointed in his model: phronetic leadership skills as an indispensable propeller of knowledge creation in organizations. Our analysis will continue with an assessment of the incorporation of practical rationality in his proposal from the point of view of the classic Western tradition. To conclude, we indicate the scope and limits of the use of phronesis in Nonaka's contribution as well as some challenges that this proposal represents for contemporary business.

\section{Knowledge-Creation in Organizations}

In recent years, "knowledge-based theories of the firm" (Nonaka \& Peltokorpy, 2006) have received increased attention from academics and practitioners in particular. This 
cognitive group of theories is founded on knowledge. Organizational knowledge creation is the process of making available and amplifying knowledge created by individuals, as well as crystallizing and connecting it with an organization's knowledge system (Nonaka et al., 2000). Although a traditional distinction between theoretical knowledge (the what) and practical knowledge (the how) has long existed, Nonaka's work offers an original contribution by differentiating between tacit and explicit knowledge.

Ikujiro Nonaka (1935-) gained international recognition with The Knowledge-Creating Company: How Japanese Companies Create the Dynamics of Innovation (Oxford, 1995), which was recognized as the Best Book of the Year in Business and Management. However, Managing Flow: A Process Theory of the Knowledge-Based Firm (Palgrave, 2008) is his seminal work, which not only demonstrates more mature thinking, but also incorporates ideas and influences from Aristotle, Whitehead, Dewey, Polanyi, Nishida and other philosophical thinkers.

This evolution is mainly characterized by a transition from information to knowledge (and even at the end of his work to practical wisdom) and from innovation from an external and objective level (products, systems) to another internal or subjective one (skills, habits). The publication of a paper co-authored with Takeuchi, The Knowledge-creating Company (Harvard Business Review, 1991), represents the first attempt to formalize his theory on knowledge creation in organizations, a task that has dominated the rest of his career. In this article, Nonaka presents the transition from conceiving organizations as machines for "information processing" -representative of western management theory from Taylor to Simon-, to a "knowledge-creating company," as some outstanding Japanese companies exemplified.

While knowledge has been placed at the center of management theories and business success in the twenty-first century (Drucker, 1959; Arrow, 1962), it also presents some problems. For example, it frequently becomes obsolete and must be renewed continually, thus demanding the creation of new knowledge. As Nonaka highlights, “To create new knowledge means quite literally to re-create the company and everyone in it in a nonstop process of personal and organizational self-renewal" (Nonaka, 1991, p. 9). An organization that creates knowledge becomes a dynamic entity that not only adapts to the environment, but also reshapes it. For a company to be a knowledge-creating entity, knowledge, which is inherently personal, has to become organizational. However, much of knowledge is highly personal and difficult to communicate to others. 
Nonaka, following M. Polanyi, calls this subjective and individual knowledge "tacit knowledge" in contrast to "explicit knowledge," which being formal and systematic can be easily shared. The movement from tacit into explicit knowledge constitutes the starting point of his proposal (Nonaka \& Takeuchi, 1995; Nonaka \& Toyama, 2007a). He justifies it as follows:

[i]n the long tradition of Western epistemology, knowledge has been defined as a 'justified true belief.' Such definition gives an impression that knowledge is something objective, absolute and context free. However, it is humans who hold and justify beliefs. Knowledge cannot exist without human subjectivity and the contexts that surround humans. (Nonaka \& Toyama, 2007a, p. 15)

That is, tacit or subjective knowledge is always associated with a context, i.e., certain people and a specific circumstance, so that its generation and transmission is necessarily related to a specific space and time where learning takes place.

Within this process, he identifies four basic patterns for creating knowledge:

1. From Tacit to Tacit, or Socialization: This is a process through which an individual shares this kind of knowledge with someone else through direct experience. It is typified, for example, in an apprentice learning from his instructor's skills. Since tacit knowledge is hard to formalize, it can only be acquired through shared experience (Nonaka et al., 2000). Empathizing with reality through actual experience.

2. From Tacit to Explicit, or Externalization: This is a process of articulating tacit knowledge into explicit through dialogue and reflection, allowing it to be shared with the organization. Conceptualizing the essence of awareness.

3. From Explicit to Explicit, or Combination: This is a process of relating, systemizing and applying pieces of explicit knowledge and information into a whole. Modeling concepts.

4. From Explicit to Tacit or Internalization: This is a process of learning explicit knowledge, making it personal in practice (learning by doing). Practicing and embodying the knowledge to create value in the form of insights for new technologies, products, services and experiences. 
It is worth highlighting that this characterization of knowledge and its different facets arose in a practical context. Nonaka's evolution is inductive, emerging from real life in organizations to form theoretical insights. In his work, he uses multiple examples from mostly Japanese companies, such as Honda, Canon, Matsushita, NEC, Sharp, and Kao, Toyota, Eisai Company, Mayekawa Manufacturing, Seven-Eleven Japan, etc. It is worth emphasizing again the importance of the spatial-temporal context: Much of knowledge creation in these companies is carried out at a specific time and in unique circumstances, and by people in specific relationships. Therein, the four stages of knowledge are not isolated, but rather reinforce each other as part of a "continuum" that forms the spiral of knowledge, which is known as SECI (figure 1). With the SECI spiral continually in rapid motion, a firm can build a synthesizing capability of knowledge to pursue both creativity and efficiency (Nonaka \& Takeuchi, 1995). Thanks to the SECI process, knowledge creation can be considered a synthesis of subjectivity and objectivity.

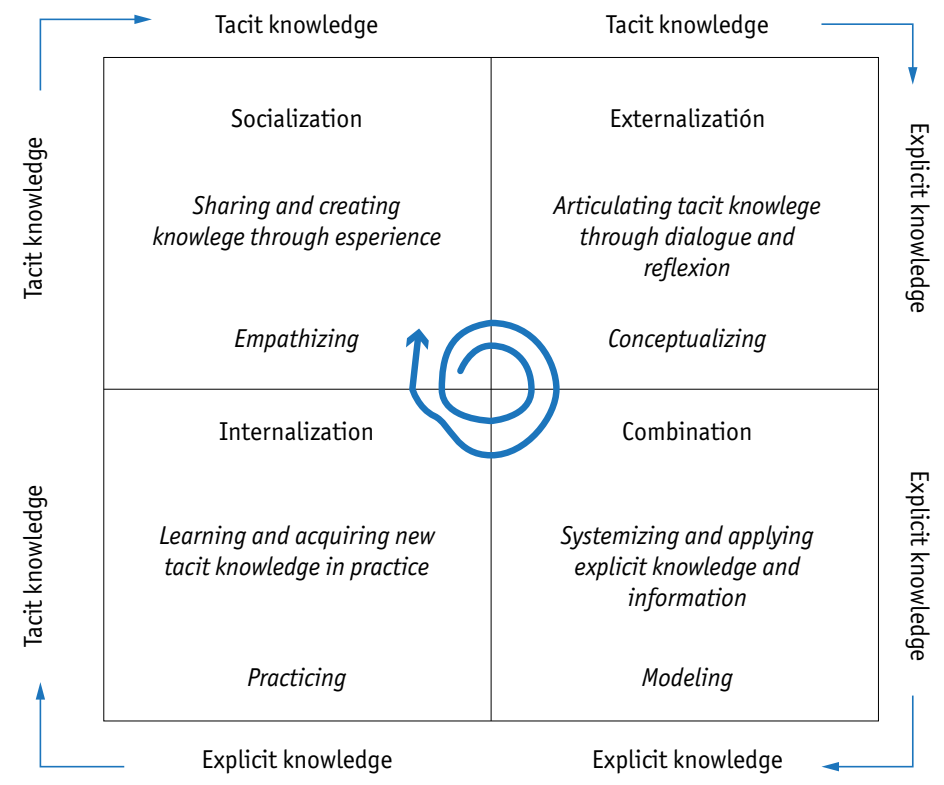

Figure 1. The knowledge-creating process: SECI model

Source: Adapted from Nonaka et al. (2008, p. 19).

In his research, Nonaka has identified several drivers for the SECI process to be effective (von Krogh al., 2000), as follows, "These enablers are related to how an organization motivates people who create knowledge, and how relationships are created between people, and between people and the environment" (Nonaka et al., 2008, p. 26). The 
model that integrates these enablers into the knowledge-creating enterprise consists of seven components (see figure 2 ):

1. Knowledge vision arises from asking the question "Why does the firm exist?" and "Why does it do what it does?" It gives direction to knowledge creation, especially in the long term. "The organization needs a value system to define what is a truth, goodness, and beauty of the firm" (Nonaka \& Toyama, 2007a, p. 19). Therefore, the firm's knowledge vision defines a consistent value system to evaluate and justify the knowledge creation that goes beyond financial matters.

2. Driving objective: A concrete concept, purpose or action standard that allows for a connection between the vision and the knowledge-creating process of dialogue and practice.

3. Dialogue (synthesis of thoughts): Different actors in an organization inevitably hold different views about the world, which are sometimes even contradictory. In order to attain synthesis in management, Nonaka supports a "soft dialectic" that incorporates conflicting views and puts them into a context (Nonaka \& Toyama, 2002, 2003, 2007a). Synthesis in knowledge creation is achieved through dialogue, which is also the best way to articulate tacit into explicit knowledge (externalization) and to systemize explicit knowledge (combination).

4. Practice (synthesis of action): Practice is another way of solving contradictions and of observing and experiencing reality as it is. ${ }^{1}$ Practice is important for sharing tacit knowledge through shared experience (socialization) and to embody explicit into tacit knowledge (internalization).

5. Ba: This word means place in Japanese and is defined as a shared context in motion in which knowledge is created, and it is essential for the human condition and action. ${ }^{2} \mathrm{Ba}$ is the foundation of knowledge creation. It is where communication and action are carried out and is guided by objectives to realize the organizational vision (Nonaka \& Toyama, 2007a). Thanks to ba, subjective points of view can be understood and shared in relationship with others. $B a$ is also a dynamic and common context in which knowledge is shared and used (Nonaka et al., 2008). According to Nonaka, knowledge is created at a specific moment and circumstances, in the "here and now". And ba allows the synthesis of both categories of time: chronological (chronos) and timely (kairos) (Nonaka et al., 2008). Ba is clearly a 
space for learning and, what is more, it is where the creation of knowledge takes place. The Japanese author thinks that the creation of knowledge includes learning, but also goes beyond it: creating knowledge is an interaction, a joint action (Nonaka et al., 2008). On the other hand, ba does not have fixed borders, but rather is open and dynamic. Belonging to $b a$ is relational, and the relationships therein are eminently functional and even episodic (Nonaka et al., 2008). In this way, it differs from communities of practice (Lave \& Wenger, 1991; Wenger, 1998). To highlight the practical and relational aspect of $b a$, Nonaka defines a company "as an organic configuration of multilayered $b a$, where people interact with each other and the environment, based on the knowledge they have and the meanings they create" (Nonaka et al., 2008, p. 39).

6. Knowledge assets: Intangibles that arise from the knowledge-creating process through dialogue and practicing $b a$. In their essence, these kinds of assets are specific to the firm; that is to say, they cannot be readily bought and sold. This includes know-how, patents, technologies, as well as the understanding to create knowledge, such as certain capabilities or social capital. ${ }^{3}$

7. The environment: An "ecosystem of knowledge" that consists of multilayered $b a$, which exists across organizational boundaries and is continuously changing. The organization creates knowledge through interaction with this ecosystem.

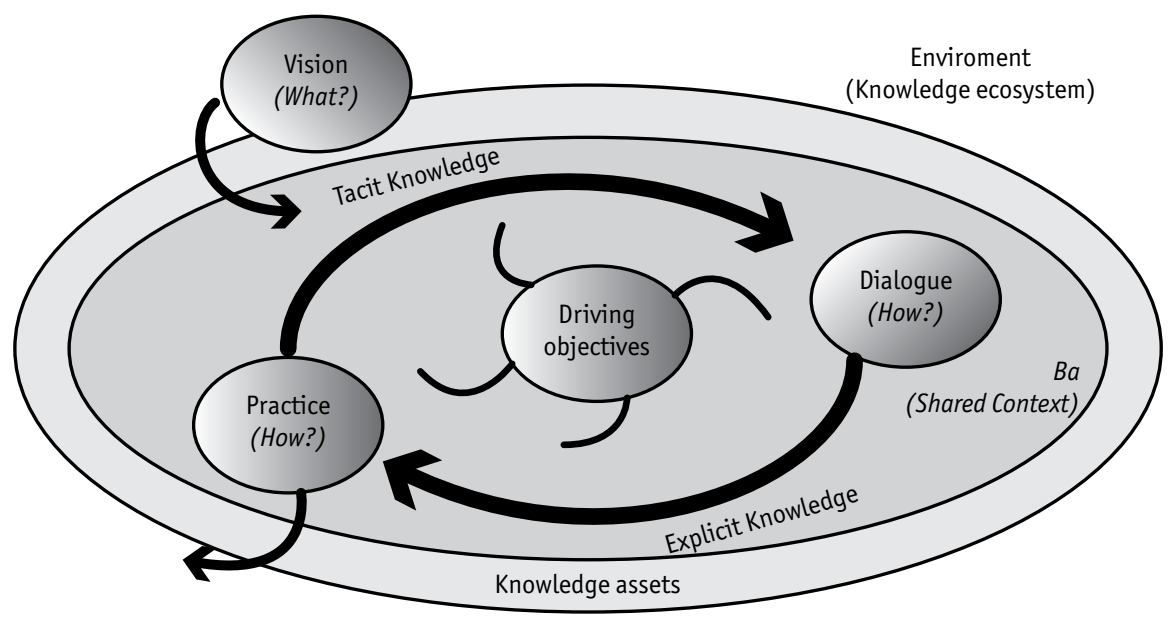

Figure 2. A process model of the knowledge-based firm

Source: Adapted from Nonaka et al. (2008, p. 27). 


\section{Phronetic Leadership}

As mentioned, from early on, Nonaka was interested in how companies develop innovative products and services by harnessing the power of knowledge-creation. Studying organizational processes more deeply lead him to recognize the importance of human agency. In his seminal and influential work Managing flow: A process theory of the knowledge-based firm, he presents a study of the management process as an art (Nonaka et al., 2008), emphasizing dynamism in organizations. In this later text, he shows the philosophical foundations of his work, especially attributing his process perspective to the English philosopher Whitehead. All the same, at this stage, he was most profoundly influenced by Aristotle and his phronesis, which lead him to the development of phronetic leadership.

In a constantly changing environment, the practical ability to make value judgments in each particular situation in relationship with others is necessary to create a sustainable competitive advantage (Nonaka et al., 2008). Aristotle called this ability phronesis, which is often translated as prudence, practical wisdom, and practical rationality (Nonaka et al., 2007b).

In the Nicomachean Ethics, Aristotle identifies three kinds of human activity: contemplation (theoria), action (praxis), and production (poiesis), each governed by a different kind of rational excellence (NE, 1140b). Thus, contemplation is governed by theoretical reason (episteme), action by ethical or practical reason (phronesis) and production by technical reason (technè). These represent three different types of knowledge, episteme is universal truth (explicit knowledge), technè is know-how or practical skill (tacit knowledge), and phronesis "is the high quality tacit knowledge acquired from practical experience that enables one to make prudent decisions and take action appropriate to each situation, guided by values and ethics" (Nonaka et al., 2008, p. 53).

Nonaka recognizes phronesis's ambivalence given that it is knowledge and a rational habit. Thus, phronesis is an intellectual virtue that amounts to being able to determine and undertake the best action in a situation to serve the common good (Nonaka et al., 2008). Phronesis, though it deliberates on the particular and selects practical means, requires the guidance of universal knowledge (episteme), the theory that underpins practice. Taking action, furthermore, always demands a technical know-how (techné). In this way, these three types of knowledge are related, although practical rationality governs execution. "If technè is 'know-how,' and episteme is 'know-why,' phronesis is knowing 
'what must be done'." (Nonaka \& Takeuchi, 2011a, p. 60). To relate these three types of knowledge in another way, we can argue that, "phronesis is the ability to synthesize a general universal knowledge with the particular knowledge of a concrete situation" (Nonaka et al., 2008, p. 54), in order to achieve the common good through action.

From these assertions, it follows that this ability is essential for a business leader. Phronesis allows leaders to make value judgments about the good to be pursued in a given circumstance. These judgments enable him to set appropriate goals and conceive of and select the means to achieve them. This is the application of universal principles to concrete situations, taking into account their characteristics and context, as well as the specific reality ahead.

Phronetic leaders use their sense of the details to 'see' or 'feel' the problems of their organizations as solvable within local constraints and develop successful plans to address the problems identified. In decision-making, phronetic leaders must be able to synthesize contextual knowledge, accumulated through experience, with universal knowledge gained through training. (Nonaka et al., 2011b, p. 464)

In order to drive phronesis in the context of a knowledge-creating company, Nonaka proposes six abilities:

1. The ability to make a judgment on 'goodness' in a particular situation. The good is a subjective value that depends on context such that people need a solid philosophical foundation in order to make a judgment of what is good. "Since phronesis is the ability to judge goodness for the common good, one has to have a higher point of view to be able to see what is good for the whole" (Nonaka et al., 2011b, p. 465).

2. The ability to share contexts with others to create $b a$, where individual views are shared and contrasted in order to transcend one's own limited perspective and create knew knowledge. It also supposes sharing emotion, care, love, trust and a sense of security (von Krogh et al., 2000). The leader should foster and manage these interactions.

3. The ability to grasp the essence of particular situations in order to contemplate the universal 'truth' or essential meaning of a particular experience. ${ }^{4}$ It requires 
attention to detail and the ability to identify changes and their implications for the common good.

4. The ability to express and communicate the essence of things, articulating and conceptualizing subjective, intuitive ideas in clear language.

5. The ability to use necessary political means well to obtain the common good. Political power is the ability to understand the contradictions in human nature and to harmonize them.

6. The ability to foster phronesis in others on the assumption that, as knowledge, individual phronetic capabilities can be transferred among people in the organization. For Nonaka, leadership in a knowledge-creating company should be adaptable and distributed so the company can respond flexibly and creatively to any situation.

Nonaka offers some recommendations for fostering collective phronesis. He first suggests encouraging the organization's members to think about the essential good in their daily activities. They should be constantly asking the question 'what is good?' in every activity they perform. However, rather than individual, the good is social. "To judge goodness for the common good, one has to be able to see what is good for the whole, even though that view stems from his or her own values and desires" (Nonaka et al., 2011b, p. 468).

He then suggests the creation of ba to experience actuality. The word "actuality" refers to a concrete situation in progress and it is influenced by his philosophy of "flow" as something that is in process of becoming. ${ }^{5}$ The creation of $b a$, an environment within which people can build mutual trust, is essential to transcend one's individuality and empathize with others. At the same time, pursuing the essence of things should become a habit, an organizational routine that allows people to see things in a larger context, rather than seeing them in isolation from each other.

In addition to organizational behavior, human experiences that imply great challenges, adversity or failure help to develop phronesis. Thus, Nonaka et also suggests creating opportunities for peak experience, as well as providing phronetic examples, which is perhaps the most important of his suggestions. Phronetic leadership can be learned by experience, and through role models that show this way of thinking and doing are of huge importance. “People learn to act with phronesis by interacting with others and by 
observing others' behavior in practice" (Nonaka et al., 2011b, p. 471). Needless to say, apprenticeship is another way to foster phronesis.

In the same way, it is also necessary to provide aesthetic and cultural experience.

According to Aristotle, phronesis is the character embodied in a good man. To foster goodness one needs experiences as a human being in every aspect of life. Especially important are aesthetic experiences and a culture of philosophy, history, literature, and the arts, which foster insights into historical and social situations. (Nonaka et al., 2011b, 472)

And last, but not least, evaluation and reward systems should promote knowledge creation and sharing. The Japanese scholar understands that the creation of high-quality knowledge is the result of the creativity of the people in the organization, which requires the presence of intrinsic motives. These motives are achieved with adequate systems of recognition, mentoring and coaching, that is, a ba that favors the free exchange of ideas (Nonaka et al., 2011b).

An original interest in knowledge, with the idea of phronesis, clearly evolved into a more ambitious purpose: wisdom: “When one relentlessly pursues excellence as a way of life, one's knowledge becomes wisdom. Management of firms in the knowledge economy needs to be based on such wisdom" (Nonaka et al., 2011b, p. 474).

Given the above characterization of phronesis, it is evident that this type of knowledge is subjective and contextual, in accordance with the nature of management. Objective knowledge- such as financial or marketing notions, methodologies and strategies - is useful, but insufficient for the exercise of leadership. The leader's learning space ( $b a)$ is a dynamic context that escapes precise definition. Prudence is learned through practice, that is to say, the leader principally learns from his own experience of leadership, and from that of other people.

\section{An assessment of Nonaka's proposal}

Some have claimed that education corresponds to the wise, whereas government corresponds to the prudent. The quintessential virtue phronesis leads both kinds of people in organizations. Nonaka's phronetic leader aligns with this tradition. 
One way to assess Nonaka's phronesis proposal is to contrast it with the Aristotelian-Thomistic teaching on practical rationality in general and on the virtue of prudence in particular. First, this requires briefly describing the classical philosophy of knowledge, as well as contrasting it with the Japanese author's contribution, and finally concluding with their similarities and dissimilarities.

From a cognitive point of view, every good first affirms different realities and different acts of knowledge. Because reality is hierarchical-some objects are more complex than others-, so is knowledge. In addition, just as there are universal and necessary realities, there are particular and contingent ones as well (Sellés, 2000). The former corresponds to theoretical knowledge, the latter to practical knowledge; and human reason recognizes both realities with different acts of knowledge: some intellectual, others prudential. Theoretical knowledge is deductive, i.e. it deducts or tests other knowledge from a few evident principles and previous knowledge. In the case of practical knowledge, the end is the beginning, which corresponds to what it wants to attain and, from there, it establishes the means necessary to attain the given end in order to make it real and effective (Aubenque, 1999).

The knowledge of both theoretical and practical reality is undertaken through acts. Every act improves through a corresponding habit. It is important to distinguish them because, in improving each act, practical knowledge also improves. The cognitive act of abstraction is common to both rationalities. Subsequent thereto, theoretical reason distinguishes between three acts of knowledge: concept, judgment and reasoning or demonstration. At the same time, practical reason has four acts: the practical concept, advice or deliberation, practical judgment and precept.

The practical concept is the knowledge of good present in reality. In this way, practical reason not only knows the truth, but also the good. The simple practical understanding or concept is the habit whereby we improve the act with which we conceive the good. It allows us to evaluate natural realities, as well man-made ones, as good. In the case of man-made ones, it enables the generation of feasible goods: it conceives of good means to achieve an end. It does not evaluate or compare, but rather discerns. In the business realm, pragmatic means are usually identified as desirable goods, e.g., cost reduction strategies as a means to increase profits. However, deliberation about the quality of these strategies lacks and instead just relies on identification. This is seen in typical brainstorming exercises. Of course, the better the acts of conceptualization, 
the more feasible the strategies will be and, therefore, understood as more attractive goods that facilitate the next act of practical knowledge.

Taking counsel (consilium) or advice follows the practical concept. It knows the things in our power, not about what cannot be otherwise. It is about the future, about what should be done, about what benefits the subject; which requires to analyze the different means according to the chosen end. Good deliberation or eubulia is the habit of advice, which allows one to review deliberations that have been made, weighing the present good and the various means in order to achieve an end. It involves mulling over a practical matter to clarify it, i.e., finding possible solutions, and helps prevent the proliferation of unfounded advice. Eubulia caters to finding commonalities in a particular type of event, as well as knowing and internalizing others' experiences in similar situations and knowing and assimilating general principles to be taken into account for any action or for generic types of actions. Following our example decision-making regarding strategies to reduce costs, after a brainstorming session that identifies a range of efficient means, it is necessary to deliberate on the feasibility of each one. This process is facilitated with the habit of good deliberation, quickly discarding unfeasible means by relying on personal experience or that of others.

The comparison between concept and reality corresponds to judgment. We reach judgments on evident truths, but we also judge things that are not fully evident, things that come up in the discourse of advice. This is practical judgment (iudicium practicum), which correspond to the particular, contingent, possible and verisimilitude. Just as necessary truth is found in the theoretical view, verisimilitude concurs with practical judgment and refers to the operable and singular. The habit of practical judgment, which Aristotle called common sense, judiciousness or synesis, allows us to judge action correctly. It enables us to determine the validity of our practical judgments. This habit is supported by experience and is forged by the repetition of accurate judgment (Aristotle, NE). It can be improved in the discovery of better and more suitable possibilities, which is not always what is best theoretically, but rather that which works best in practice. A means should not be judge as an absolute good, but as the best in relation to other possible means (Aubenque, 1999). Following the example of cost reduction, elective judgment is subject to the strategies that are feasible at that moment, choosing the most likely one with attention on all the circumstances, including suitable personnel, available technologies, favorable context, etc. 
Commanding (praeceptum, imperium) is described as the act that induces the right way of proceeding; it is not of the will, but rather is a rational act. It prescribes doing something to achieve an end and is the highest act of practical reason because it is closest to the intended end. Its corresponding habit is phronesis or prudence, which anticipates the future, presupposing the intended purpose, deciding on the best mean that lead to this end and moving toward doing. The virtue of phronesis is easier to recognize in specific people than to try to describe it. This is what Aristotle did when identifying in historical figures such as Pericles the good use of practical rationality. Similarly, in business reality, it is easier to see this virtue embodied in great entrepreneurs or managers than to characterize it. It is their performance in concrete situations that makes them paradigms of virtue, and not their analysis or judgments, which are assumed to have been executed well.

Nonaka includes all acts and habits of practical reason under phronēsis, i.e., concept, advice, judgment and commanding. For example, i) We can identify the habit of simple practical understanding or concept when he says that a constitutive ability of Phronēsis is to capture the essence of situations and particular entities: "It is the ability to fathom intuitively the true nature and meaning of the people, things, and events" 6 (Nonaka et al., 2008, p. 58). ii) Deliberation or advice when he says that phronēsis "is the ability to synthesize a general universal knowledge with the particular knowledge of a concrete situation" (Nonaka et al., 2008, p. 54). iii) Judgment is explicitly mentioned in the first constitutive ability of phronēsis: to make judgments about "goodness:" “Judging goodness refers to the ability to practice one 's moral discernment on what is 'good"' (Nonaka et al., 2008, p. 55). iv) The commanding or precept clearly shown in the operative and pragmatic character that phronēsis possesses. The preceding sentence ends: "and act on that judgment on practical level according to the particular situation" (Nonaka et al., 2008, p. 55).

Aristotle's analysis of identifying the various acts of practical knowledge is remarkable. Not so with Nonaka: He identifies different abilities that make phronesis, but does not break them down into hierarchical acts of knowing in which each require the former. Indeed, there is correspondence, but no correlation between acts and habits with Nonaka's phronessis. Although this topic goes beyond the scope of this article, perhaps it is because he does not define knowledge as an act, as understood by the classics, but as a process. Certainly, learning is a process but knowing is an act. ${ }^{7}$ 
Phronesis, like every virtue, refers to the contingent, or that which has a variety of possibilities (Aubenque, 1999). It should be exercised in concrete space and time; in this case within the company and its circumstances, which correspond to true spheres of knowledge, learning and action. We could say that the company, each company, is the learning space par excellence for its members. Phronesis is not the application of some theoretical principles in the abstract, but rather is circumstantial application that always requires practical knowledge of the here and now. In addition, virtue in Aristotle always refers to the opportune moment, when the action is good: kairós (Aubenque, 1999). Once again, practical wisdom is required to decide and act on a favorable occasion- not before or after, which could make a decision futile. The importance that Nonaka assigns to $b a$ reinforces this idea, since, for the Japanese author, $b a$ is defined as a shared context in motion in which knowledge is created and it is essential for the human condition and action.

The habit of prudence is developed in practice by striving to make prudent actions. Upon making a mistake, action is corrected. Right reason comes from correct reason, to be corrected. In this way, practical reason increases knowledge. Through the habit of prudence, we realize our actions, ordering them to the intended purpose and in the right way. When we know them, we distinguish, for example, between saying on particular issue, "I'm going to go behind your back" or "I will be loyal." After distinguishing them, one corrects the first and adheres to the second, with the resulting consequences. Nonaka coincides with this reasoning by stating that experience is key to acquiring phronesis. Organizations contribute to the development of prudence in their leaders when they provide opportunities for quality learning, especially in practice (Nonaka et al., 2008).

As stated, it is possible to make an important distinction between technical knowledge (techne $)$ and prudence (phronesis) both conceptualized by Nonaka as tacit knowledge (Nonaka et al., 2008). They differ inasmuch as technique improves the external work, while phronesis betters the person who works. The craftsman uses technique for the proper conduct of his craft, which does not necessarily require prudence. In an extreme example, it could be said of a thief who plies his office with solvency, with art, but it does not wisely but shrewdly. Instead of virtuous, he is considered skillful because he does not look toward being better, nor toward the good of others. At the business level, we could say the same. A person is inseparable from his actions. To get ahead a company is not confined to implementing a kind of productive rationality (techne $)$, it is rather meant to ensure that all who participate can find a path toward self-improvement, making them better in the process (phronessis). Prudence is thus closely related to human 
perfection, which in turn is related to the good. What is good for man is what improves him, making him grow in his rational powers, i.e., in intelligence and the will to know more and to love what is best.

Nonaka appreciates this essential aspect of prudence, very clearly relating it to the good. He initially exemplifies goodness as what the customer requires for a product or service. That is, he limits the practical value judgment of the good to customer evaluation. This has the danger of making the good context dependent or subjective. It is unethical to provide customers with everything they want. T.V. programs that encourage violence might have large audiences, but they are not intrinsically good. Fortunately, the Japanese author is aware of the danger of subjectivity for individual goods and proposes a broader good as a final guidance for prudence, i.e., the common good. Initially, he refers to it as what is good for the whole (Nonaka et al., 2008). Later it relates to the pursuit of excellence.

In the end, the ultimate goal for both individuals and organizations must be the relentless pursuit of excellence. Indeed, MacIntyre (1984) sees the ultimate goal of practice as achieving 'standards of excellence,' an idea that can also be found in Aristotle. (Nonaka et al., 2008, p. 57)

Thus, Nonaka proposes cultivating phronesis through the relentless pursuit of excellence and quality in action. "The phronesis is acquired through the effort to perfect the one's craft, which makes one a virtuous artisan" (Nonaka et al., 2008, p. 53).

We can, however, identify some failings in this project. For Nonaka, the good obtained is essentially external, i.e., perfection, excellence, quality work produced by a talented artisan, however, the inner good is not well defined. In a more classical proposal, it is clear that the good obtained by virtue is first intrinsic and relates to the improvement of man. The extrinsic good usually accompanies the intrinsic good, but not always, because in achieving a good work many factors collide, including others' work, input quality and required information, among other things. Nonaka emphasizes phronēsis as a set of abilities for the (external) common good, but underestimates its quality of virtue as understood by the Aristotelian-Thomistic tradition. Aristotle distinguishes between action and making (or production), between praxis and poiesis. Man does not produce exclusively, but rather mainly acts. With action, man makes himself. Every acting individual can improve. Nonaka's underestimation man's improvement through 
phronēsis is more evident when we realize that the Japanese thinker does not consider the will and how virtue improves it in the exercise of phronesis.

\section{Phronetic leadership's challenges}

From the very beginning of management literature, business leadership has been extensively studied and analyzed. Henri Fayol (1916) and Chester Barnard (1938) were pioneers in identifying the importance of leaders and their roles or functions. Along the way, charismatic, transactional, transformational and service are some of the adjectives that describe the noble task of directing people towards a goal. As we have seen, Nonaka applied another adjective to leadership, namely "phronetic." Despite how much the Japanese author and his disciples have written about it, phronetic leadership's development and implementation in contemporary business firms still faces many questions and challenges. Some of them include how to teach this type of leadership, how this type of leader can survive in the contemporary business environment that many consider amoral- and even immoral, and how to form phronetic communities in an individualistic culture such as the one that dominates Western organizations. In what follows, we will give some guidelines that may be of help to answer these questions.

Faced with skepticism in business, largely as a result of recent ethical scandals, phronesis is an aid to good behavior. Nonaka reminds us that practical wisdom is "a virtuous habit of making the 'right' decisions and taking 'right' actions in the particular context with values and ethics that serve the common good" (Nonaka, 2012, p. 18). Thanks to phronesis, people can identify greater likelihoods when faced with specific situations and communicate them to others, showing that the right thing here and now is good for everyone, favoring dialogue that allows shared reasons and agreeing on common actions. Far from being a utopian ideal, prhonesis as a practical excellence could be a good antidote to amorality.

On the other hand, virtue is attractive and effective in the example of the prudent man, whose action guides and whose word counsels others.

Truth and good are not imposed on the world through computers, books, newspapers, polemics or the use of force, but through the influence of men and women who teach the truth while living it, and who teach good while they do it. (Morales, 2011, p. 25) 
Nonaka himself tells a story of teaching ethics, when it was not the CE0, but rather his collaborators, who reasoned their ethical position to him. It didn't involve just any leader, but rather Soichiro Honda, the legendary founder of the renowned automotive company, a character whom Nonaka considered a phronetic leader. When Honda was developing a low-emissions automobile engine, Soichiro declared that the new engine would put the company in a position to beat the automakers in the United States, who were then opposing the Clean Air Act. Honda's engineers objected, saying that they were developing the engine in order to fulfill social responsibilities, not just to beat competition. They were doing it for their children, they said. The story goes that Honda was so ashamed of himself when he heard this reason that he decided it was time to retire (Nonaka \& Takeuchi, 2011).

When most approaches that take on the crisis of capitalism tend to oppose collectivism and liberal individualism, Nonaka seeks a dialectical synthesis between them.

The SECI model is a framework for overcoming the dualities of free will versus environmental determinism, and agency versus structure... This process is not determined by environment or free will but occurs somewhere in between, in the dialectical relationship between the individual subject and the environment that emerges in dialogue and practice, in a dynamic synthesis that changes both. (Nonaka et al., 2008, p. 47)

For Nonaka, since relationship is essential to the person, the company should be constituted as a community, as a group of people relating to one another, and not as a sum of individuals (Nonaka et al., 2008). In other words, there is no trade-off between individual action and social insertion. In this way, he moves away from self-sufficient individualism, predominant in mainstream economic thought, as well as from collectivism, in which the subject vanishes in the structure. ${ }^{8}$ Some contemporary social thinkers are trying to achieve a balance between both positions (Caillé, 2000). They claim that structure certainly influences human behavior, but that humans are also capable of changing the social structures they inhabit (Contu \& Willmott, 2005). Nonaka's position is akin to the latter view and proposes a dialectical synthesis between both theses through phronetic leadership.

Western individualism maintains a strong legacy in economic thought and organizational theory. When the individual is isolated, she has nothing in common with others, to whom she relates through a transaction that occurs in the market or a contract that 
is established in the company. It is often the case that economic thought views the person as Homo economicus, where individual relationships are defined by contract. This builds external, rather than internal, relationships because the individuals involved do not share experiences, meaning that individuals exist apart from each other without community (Nonaka et al., 2008). But, as Nonaka has argued multiple times, man creates knowledge with others; he never does so alone (Nonaka et al., 2000b). Thus, the relationships between individuals - far from being an accessory, and therefore something with a cost that must be avoided or at least diminished (minimized in economic terminology) - are a necessary reality because man can only be understood in relationship: “[a] person exists in relation to others forming a community, and at the same time each person has unique characteristics and a unique experience of the community as a person-in-community" (Nonaka et al., 2008, p. 43).

As a consequence, in his attempt at an individual-collective synthesis, Nonaka uses notions from the classical tradition. For Aristotle, phronesis is communal, just as ethics and politics are-one learns to be prudent among the prudent. The challenge that then emerges is how to train a phronetic leader.

In his famous article published in the Harvard Business Review, The Wise Leader, Nonaka offers some insights for answering this question. Practical wisdom should be nourished by theoretical learning and the experiences of others, relating them to one's own experiences. Knowledge begins with the humanities, the liberal arts of the Anglo-Saxon academy. In this way, the manager will be able to broaden his range of appreciated assets in order to identify them in the situations he will face. The first skill that every prudent leader should have is the, ability to make a judgment on goodness (Nonaka et al., 2008). Nonaka usually refers to Steve Jobs as a phronetic leader, citing his famous phrase: “Technology alone is not enough. It's technology married with the liberal arts, married with the humanities, that yields the results that makes our hearts sing" (Nonaka, 2012, p. 21). Nonaka promotes a program to help create leaders who apply practical wisdom in Japanese companies called The Knowledge Forum. He proposes a shared context $(b a)$ where executives can cultivate character and integrity by interacting with scholars of philosophy, history, literature, political science, and economics to deepen their understanding of the humanities - (Nonaka \& Takeuchi, 2011). This training allows the phronetic leader to expand the goods that he can identify in the different situations he faces. Not all goods in the business realm are pragmatic, and also include ethical, aesthetic and civic ones. Thus, in business decisions, economic and social ends converge. 
The second aspect is the development of better criteria to face and resolve business decisions in a prudential manner, for which the concrete example of other leaders is fundamental. The way

a community teaches its junior members what a good captain, farmer or manager is, not in abstracto but in concreto, by observing and, if possible, participating in historically developed practices. Consequently, teaching practical skills is not about teaching abstract rules and technical means for the achievement of exogenously given goals, but, in effect, initiating the taught into the traditions of a community of practitioners teaching them both the communal goals and the means for achieving them. (Tsoukas \& Coumings, 1997, p. 670)

In the aforementioned program, activities that facilitate this enrichment are designed. Nonaka admits, however, the most valuable experience corresponds to that which is pertinent to the work itself. Thus, a potential leader grows most in practical wisdom through participating in activities in the company. People learn to understand what phronesis is through practice, but they can hardly learn without help. That is why Nonaka believes that one of the phronetic leader's essential skills is to promote phronesis in others to build a sustainable organization (Nonaka et al., 2008). Training on the job, the emulation of emblematic managers in the company and mentoring in a teacher-apprentice relationship (Nonaka \& Takeuchi, 2011) represent various ways, among many, to develop phronesis.

\section{Conclusions}

Nonaka proposes an invaluable reflection in the world of business, incorporating the research and application of practical rationality in general, and phronesis in particular, to the leadership of the knowledge-based company. Several scholars disagree on the pertinence of the research and the findings reached for organizational sciences (Sandberg \& Tsoukas, 2011). Some explain this inconsistency between theory and practice based on the fact that the social sciences have elevated theoretical rationality. Accordingly, most of the theories within business management are unable to capture the logic of practice because they have been developed in the context of scientific rationality and fail to connect with organizational practice or its participants. Alternatively, they propose the use of practical reason as approach and methodology. It is a new and promising field, but can lead to difficulties because this approach will never reach the rigor and consistency 
that the sciences are accustomed to. This is so partly because the research field is pragmatic and contingent, always contextual and filled with subjectivity (Flyvberg, 2001).

Phronessis plays a leading role in practical reason. Among the classics, especially in the Aristotelian-Thomistic tradition, it is regarded as a key virtue for leaders. Aquinas teaches, "It is proper to a man to reason and be prudent in so far as he has a share in ruling and governing" (STh II-II, q. 47, a. 12). It is a habit attached to practical reality. For the prudent man, to govern is to improve, starting with what exists and with a clear ideal of achieving the best possible. Nonaka belongs to this tradition because he considers practical wisdom a guiding force for the knowledge-based company. He identified six abilities that a phronetic leader must possess and develop, many of which he exemplifies with organizational practices that can guide those who want to properly lead knowledge creation in companies.

Although the acts and habits of practical knowledge correspond with the abilities that Nonaka assigns to phronessis, it should be noted that they lack correlation. The acts that Aristotle identifies are hierarchical: they range from minor to major knowledge. Realizing this hierarchy and this dependence is key to the improvement of practical knowledge: taking care of each of the acts implies greater verisimilitude. And it enables us to better attain the good and choose the most appropriate means to the desired end.

Phronessis is both an intellectual habit and a moral virtue, thus it is important for understanding the use of the will in the various acts of prudence. Irresolution, emotional biases in decisions and lack of diligence in performance are voluntary errors, not intellectual mistakes. It is certainly arguable that Nonaka, like many scholars of business management, has a reductive vision of personal action. By understanding human praxis, and therefore business practice, as exclusively based on knowledge, it neglects another human power in action, i.e., the will. Perhaps there is a bias towards the preeminence and autonomy of reason: the will and action follow necessarily the known good.

Justice, fortitude and temperance accompany prudence as cardinal virtues, which perfect the will. The business leader derives other strengths from them, including: magnanimity and courage, confidence and resilience. Hopefully we aspire Nonaka and his disciples cross the bridge from intelligence to the will accompanied by phronesis and conclude, as the classics did, that the virtues are of great importance, while, at the same time, proposing practices that allow for their use and development in the knowledge-creating company. This is not a trivial topic for organizations. 
Nonaka's attempt to give theoretical support to their work and to seek conceptual explanations to the practical realities observed in organizational knowledge and leadership is laudable. In doing so, the Japanese writer has gleaned contributions from the classics and other traditions. Ikujiro Nonaka has taken an important step in the right direction and is in good company. Finally, as he himself argues,

CEOs cannot be content to analyze situations using empirical data and deductive reasoning; they must also make inductive jumps according to their ideals and dreams. If they aren't idealistic, they simply can't create new futures. Being idealistic isn't enough, though. Leaders must also be pragmatic-looking reality in the eye, grasping the essence of a situation, and envisioning how it relates to the larger context-if they are to judge what they must do right then and there to achieve the common good. CEOs have to become idealistic pragmatists, which is why they must turn the dual quest for knowledge and practical wisdom into a way of life. (Nonaka \& Takeuchi, 2011a, p. 67).

Compliance with Ethical Standards:

Ethical approval: This article does not contain any studies with human participants or animals performed by any of the authors. Conflict of interest: Both authors declare that they have no conflicts of interest.

\section{References}

Aquinas (2006). Summa Theologiae. Cambridge: Cambridge University Press.

Aristotle. Nicomachean Ethics. The Internet Classics Archive. Retrieved: October of 2015, http:// classics.mit.edu

Aubenque, P. (1999). La prudencia en Aristóteles. Barcelona: Grijalbo - Mondadori.

Barker, C. (2005). Cultural Studies: Theory and Practice. London: Sage Publications.

Barnard, C. (1938/1968). The Functions of the Executive. Cambridge: Harvard University Press.

Caillé, A. (2000). Anthropologie du don. Le tiers paradigme. Paris: Descleée de Brouwer.

Contu, A., \& Willmott, H. (2005). You spin me round: The realist turn in organization and management studies. Journal of Management Studies, 42(8), 1645-1662.

Csikszentmihalyi, M. (1990). Flow: The Phsycology of Optimal Experience. New York: Harper and Row. Fariñas, G. (2011). Ikujiro Nonaka y la teoría procesal de la empresa basada en el conocimiento. Una aproximación cognitiva. Tesis doctoral. Universidad de Navarra, Instituto Empresa y Humanismo, http://dspace.unav.es/dspace/handle/10171/20870 
Fariñas, G. (2015). La vuelta a la phronesis aristotélica en la teoría y la práctica de la empresa creadora de conocimiento de Ikujiro Nonaka. Revista Empresa y Humanismo, XVIII(1/15), 41-80.

Fayol, H. (1916/2013). General and Industrial Management. New York: Martino Publishing.

Flyvberg, B. (2001). Making social science matter: Why social inquiry fails and how it can succeed again. 0xford: Cambridge University Press.

Gueldenberg, S., \& Helting, H. (2007). Bridging 'The Great Divide': Nonaka's Synthesis of 'Western' and 'Eastern' Knowledge Concepts Reassessed. Organization, 14(1), 101-122.

Lave, J., \& Wenger, E. (1991). Situated learning: Legitimate Peripheral Participation. New York: Cambridge University Press.

Morales, J. (2005). El hombre nuevo. Madrid: RIALP.

Nonaka, I. (1991). The Knowledge-creating Company. Harvard of Business Review, 69(6), 96-104.

Nonaka, I. (2012). Leadership in Knowledge-based Organization - A New Frontier of The KnowledgeCreating Theory. Retrieved: August, 2018, http://siteresources.worldbank.org

Nonaka, I., \& Konno, N. (1998). The concept of 'ba': Building a foundation for knowledge creation. California Management Review, 40(3), 40-54.

Nonaka, I., \& Peltokorpy, V. (2006). Objectivity and subjectivity in knowledge management: A review of 20 top articles. Knowledge and Process Management, 13(2), 73-82.

Nonaka, I., \& Takeuchi, H. (1995). The knowledge-creating Company. New York: Oxford University Press.

Nonaka, I., \& Takeuchi, H. (2011a). The wise leader. How CEOs can learn practical wisdom to help them do what's right for their companies -and society. Harvard Business Review, $89(5)$, 58-67.

Nonaka, I., \& Toyama, R. (2007a). Why Do Firms Differ? The Theory of Knowledge-Creating Firm. In Ichijo, K., \& Nonaka, I. (eds.) Knowledge Creation and Management. New Challenges for Managers (pp. 13-31). New York: 0xford University Press.

Nonaka, I., \& Toyama, R. (2007b). Strategic management as distributed practical wisdom (Phronesis). Industrial and Corporate Change, 16(3), 371-394.

Nonaka, I., Toyama, R., \& Hirata, T. (2008). Managing flow: A process theory of the knowledgebased firm. New York: Basingstoke England, Palgrave Macmillan.

Nonaka, I., Toyama, R., \& Konno, N. (2000a). SECI, Ba and Leadership: A unified model of dynamic knowledge creation. Long Range Planning , 33(1), 5-34.

Nonaka, I., Toyama, R., \& Nagata, A. (2000b). A firm as a knowledge-creating entity: A new perspective on the Theory of the Firm. Industrial Corporate Change, 9(1), 1-20.

Nonaka, I., Toyama, R., \& Peltokorpi, V. (2011). The distributed and dynamic dimensions of human capital. In Burton-Jones, A., \& Spender, J. Oxford Handbook of Human Capital (pp. 459-476). 0xford: 0xford University Press. 
Sandberg, J., y Tsoukas, H. (2011). Grasping the Logic of Practice: Theorizing through Practical Rationality. Academy of Management Review, 3(2), 338-360.

Sellés, J. F. (2000). Razón teórica y Razón práctica según Tomás de Aquino. Cuadernos de Anuario Filosófico, 101, Pamplona: Universidad de Navarra.

Tsoukas, H., \& Cummings, S. (1997). Marginalization and recovery: The emergence of Aristotelian themes in organization studies. Organization Studies, 18/4, 655-683.

Von Krogh, G., Ichijo, K., \& Nonaka, I. (2000). Enabling Knowledge Creation: How to Unlock the Mystery of Tacit Knowledge and Release the Power of Innovation. New York: Oxford University Press.

Wenger, E. (1998). Communities of Practice: Learning, Meaning, and Identity. New York: Cambridge University Press.

\section{Notas}

1 Nonaka follows a pragmatist philosophy (Dewey) and Schön's idea of "reflection in action." (Nonaka \& Toyama, 2007a, p. 22). Nonaka quotes The Reflective Practitioner (Schön, 1983).

2 Nonaka highlights the importance of place in a variety of philosophers, such as Plato (chora), Aristotle (topos), or Heidegger (ort) (Nonaka \& Toyama, 2007a). Ba is a place that can be physical (e.g., an office), virtual (e.g., an e-mail), mental (e.g., shared experiences) or a combination of them. See Nonaka \& Konno (1998, p. 40).

3 He uses the Japanese word kata ("pattern" or "way of doing things") to emphasize the importance of "creative routines." "Kata is different from a routine in that it contains a continuous self-renewal process. The three steps of kata-shu (learn), ha (break) and $r i$ (create)- mean that one learns certain patterns first, then breaks away from them and creates new patterns once the old are totally mastered" (Nonaka \& Toyama, 2007a, p. 25).

4 In order to do so, he gives examples from some Japanese practices that help to identify the root of a problem, for instance, in the case of Toyota they ask 'why?' up to 5 times (Nonaka et al., 2008).

5 According to Nonaka, ba resembles the concept of "flow" as set forth by psychologist Mihaly Csikszentmihalyi (1990).

6 It seems contradictory that, in an intuitive way, a full understanding of the essence of things emerges. According to Aristotle, abstraction, not intuition, captures the essence of things beyond the particular. In this conception of intuition, Nonaka draws on other 
epistemological sources, perhaps the process philosophy: For Whitehead, prehension ("not cognitive apprehension") is key (Fariñas, 2011).

7 In real life, we tend to see obviating processes that are composed of acts. An analogy to this reality is a film composed of frames. The film is the process, but we could not watch it without the frames that compose it. Improving a movie involves improving its frames, acting on them. This is what the Aristotelian theory of knowledge proposes for human life.

8 Among the doctrines that defend the preeminence of "the structure," structuralism and Marxism are included, that is, doctrines that affirm that, "the whole is more than the sum of the parts." For them, individual performance can be explained mostly by the functioning of society as a structure. Theories that defend "individual agency" affirm that individuals possess the capacity to construct and reconstruct their environments, including methodological individualism and social phenomenology.

Licencia Creative Commons CC BY 4.0 